\title{
Expedition Oe: A Visual-storytelling map on Rote Island's Lakes
}

\author{
Dany Laksono ${ }^{1}$, Atriyon Julzarika ${ }^{1,2^{*}}$, Luki Subehi ${ }^{3 *}$, Hanhan A. Sofiyuddin ${ }^{*}$, Esthi K. Dewi2 ${ }^{*}$, Kayat $^{*}$, Media Fitri Isma N. ${ }^{*}$ \\ 1,2 Universitas Gadjah Mada, Yogyakarta \\ 2 Lembaga Penerbangan dan Antariksa (LAPAN) \\ ${ }^{3}$ Lembaga Penelitian dan Ilmu Pengetahuan (LIPI) \\ ${ }^{4}$ Kementrian Pekerjaan Umum dan Perumahan Rakyat (PUPERA) \\ ${ }^{5}$ Kementrian Lingkungan Hidup dan Kehutanan (KLHK) \\ ${ }^{6}$ Kementrian Kelautan dan Perikanan (KKP)
}

\section{Article History:}

Received 13 November 2018

Received in revised form 22 January 2019

Accepted 23 January 2019

Available online 31 January 2019

\section{Keywords:}

Stroytelling map, Rote Island, WebGIS

Corresponding Author:

Atriyon Julzarika

Email: verbakhov@gmail.com

\begin{abstract}
Rote Island has long been known as a tourism destination, especially for its beaches and small islands which are well known surfing spots. However, many other aspects of Rote Island, such as its inland waters, left unexplored and are unknown to tourists or stakeholders. The lack of infrastructure is one of the factors causing underdevelopment in these areas. This paper reports the outcome of an expedition set to uncover the uniqueness of Rote Island's tourism potential, especially on its inland waters. The expedition involves multidisciplinary researchers from some of Indonesian institutions related to inland waters, such as LAPAN, LIPI, PUPERA, KLHK and KKP to conduct some preliminary research on Rote Island's saltwater lake. Mobile devices equipped with GIS software were used to obtain data during the survey. Some of the findings including the misleading toponyms found in online sources of the lakes, the biogeophysical condition of the lakes, as well as vegetations and wildlife of the area. The Rote Island Snake-necked Turtle (Chelodina Mccordi) is one of the near-extinct species which habitat needs to be identified and wellpreserved, thus tourism should take into account natural preservation in the lakes and its surroundings. Based on the results we suggest that a Geopark should be initialized in and around Rote Island's lakes. These findings are presented as a storytelling map, both to attract tourism and to emphasize the geospatial aspects of the lakes. A WebGIS is also developed to integrate data from different institutions to aide decision making. The result is geopark4rote.com, which present the storytelling map and WebGIS to be used by tourist and decision makers alike to explore the richness of Rote Island through geospatial data.
\end{abstract}

(C) Author(s) 2018. This is an open access article under the Creative Commons Attribution-ShareAlike 4.0 International License (CC BY-SA 4.0).

\section{Pendahuluan}

Secara geografis, Pulau Rote (Roti Island) terletak pada $10^{\circ} 25^{\prime}$ - $11^{\circ} 00^{\prime}$ Lintang Selatan dan 121 ${ }^{\circ} 49^{\prime}$ - $123^{\circ} 26^{\prime}$ Bujur Timur (Kabupaten Rote Ndao, 2018). Posisi geografis ini menyebabkan Pulau Rote merupakan pulau paling selatan dari Negara Kepulauan Republik Indonesia. Pulau Rote sendiri terdiri dari setidaknya 94 buah pulau besar dan kecil yang termasuk dalam wilayah Kabupaten Rote Ndao.

Berkat posisi geografis serta bentuk topografinya tersebut, Pulau Rote memiliki keanekaragaman hayati yang sangat beragam. Demikian pula, struktur geologis
Pulau Rote menyebabkan berbagai bentukan alam yang sangat menarik dan memiliki potensi wisata yang cukup tinggi. Diantara keunikan yang terdapat di Pulau Rote adalah sejumlah danau yang tersebar di seluruh wilayah Pulau Rote, dari bagian barat hingga ke timur. Sebagian danau di Pulau Rote memiliki keunikan, yaitu kadar garamnya yang sangat tinggi sehingga menjadikan beberapa danau tersebut sebagai danau laut mati (Nikodemus, Susanto, \& Sudira, 2004). Kondisi danau air asin ini juga memungkinkan berkembangnya berbagai species hewan maupun tumbuhan yang unik, sehingga menambah kekayaan hayati Pulau Rote secara keseluruhan (Zitierung, Wright, \& Lewis, 2012). 
Lebih jauh lagi, Pulau Rote merupakan habitat alami dari kura-kura leher ular (Chelodina mccordi rhodin) yang saat ini dinyatakan dalam status hampir punah (critically endangered). Perubahan ekosistem alami dan aktivitas manusia menyebabkan berkurangnya populasi kura-kura ini secara drastic pada akhir dekade 90an (Endarwin, UlHasanah, Vazquez, \& Kusrini, 2005). Usaha pengembalian kura-kura leher ular ke habitat aslinya di Pulau Rote terus dilakukan hingga saat ini.

Meskipun memiliki potensi wisata yang sangat besar, namun sayangnya wisata di Pulau Rote, khususnya terkait dengan perairan darat, masih kurang berkembang dibandingkan dengan wisata pantainya. Untuk itu perlu dilakukan pemetaan potensi pariwisata dari danau-danau di Pulau Rote berikut fitur unik yang terdapat di masingmasing danau. Penelitian ini menguraikan mengenai aspek geospasial dari expedisi Pulau Rote oleh Julzarika dkk. (2018).

Dengan berlakunya Undang-undang Informasi Geospasial No. 4 Tahun 2011, berbagai data spasial terkait dengan perairan darat dapat diperoleh dari wali data yang berbeda. Dengan demikian, pembangunan sistem informasi berbasis spasial dapat dilakukan dengan mengkombinasikan berbagai data yang terkait mengenai perairan darat di seluruh Indonesia. Selain itu, penelitian ini juga dilakukan sebagai studi pendahuluan untuk memetakan ekosistem danau yang sesuai untuk menjadi habitat kura-kura leher ular di Pulau Rote. Metode visualisasi dalam bentuk storytelling map digunakan untuk menampilkan informasi mengenai potensi pariwisata khususnya danau di Pulau Rote.

Storytelling map dipilih karena efektivitas penyampaian pesan dalam bentuk visualisasi peta. Kosara dan Mackinlay (2013) menyebutkan storytelling dalam konteks visualisasi sebagai suatu 'tahapan berurutan, dimana tiap tahap dapat berisi kata-kata, gambar, visualisasi, video, atau kombinasi dari komponen tersebut'. Sebagai contoh, Graves (2015) menyusun storytelling map sebagai media komunikasi dan community engagement dalam konservasi air tanah. Lebih jauh, Kerski (2015) mengulas mengenai peranan storytelling map dalam membangun geo-awareness. Feeney (2017) dalam studi mengenai peranan peta dalam peningkatan pariwisata menunjukkan bahwa storymap merupakan salah satu media untuk menarik wisatawan pada tempat wisata tersebut. Platform web yang interaktif memungkinkan pengguna untuk lebih jauh menggali informasi yang disediakan oleh pembuat cerita. Thöny, dkk, (2018) menggunakan web dalam platform 3D untuk menyajikan interaktivitas sebagai sarana storytelling. Cortes (2018) merangkum berbagai metode storytelling interaktif dan menyajikan sebuah framework konseptual sebagai platform untuk bercerita, dengan ESRI Story Maps sebagai salah satu contoh platform semacam ini.

Dengan mengkombinasikan data dari berbagai instansi serta hasil survey lapangan dari Julzarika dkk. (2018) dalam bentuk story maps dan WebGIS, aspek geospasial dari persebaran danau di Pulau Rote dapat dikomunikasikan kepada masyarakat umum, turis potensial serta stakeholder tanpa memerlukan keahlian teknis yang tinggi. Platform ESRI Story Maps digunakan untuk menyajikan data yang diperoleh dari lapangan untuk menyusun narasi interaktif mengenai Pulau Rote.

\section{Data dan Metodologi}

2.1. Lokasi penelitian dan bahan pendukung

Expedisi Rote oleh Julzarika dkk. (2018) dilaksanakan pada tanggal 26 sampai 30 Agustus 2018 di Pulau Rote, khususnya pada danau-danau serta bagian perairan darat yang terletak di bagian timur dan barat Pulau Rote.

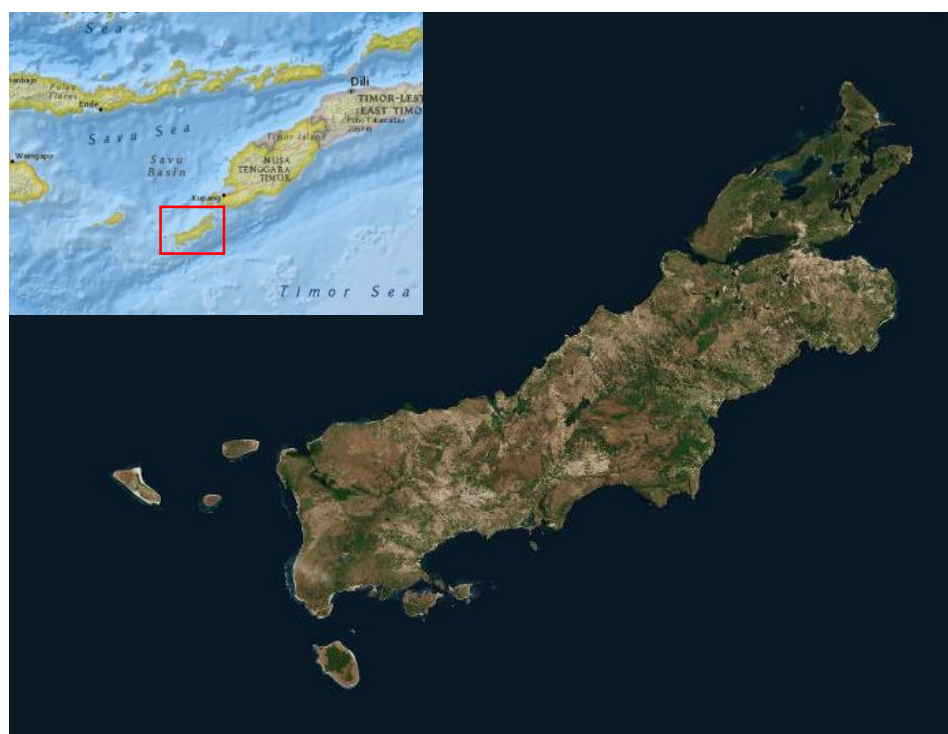

Gambar 2.1 Lokasi Penelitian (Pulau Rote)

Penelitian ini mengkombinasikan antara data lapangan dari hasil survey, pengamatan citra satelit, keterangan warga lokal serta data spasial dari berbagai instansi untuk dikombinasikan dalam sebuah storytelling map serta WebGIS. Sumber data tersebut antara lain:

a. Survey Lapangan. Dilakukan untuk memperoleh data berupa foto dengan atribut geospasial (geotagged photos), tracking jaringan jalan, serta data lain yang terkait (misalnya titik dan ukuran jarak). Survey lapangan dilakukan dengan menggunakan perangkat mobile (handheld phone) dengan perangkat lunak SWMaps.

b. Data OpenStreetMap (OSM) dalam format vector digunakan untuk membantu kegiatan survey lapangan sebagai data awal untuk tracking pada perangkat SWMaps

c. Citra satelit, digunakan sebagai latar sekaligus layer analisis pada WebGIS yang akan dibangun. Dalam penelitian ini digunakan citra Landsat multitemporal yang dapat menampilkan citra satelit 
Landsat di Pulau Rote sesuai dengan kriteria yang diinginkan, misalnya tutupan awan atau periode akuisisi tertentu. Analisis yang digunakan pada citra satelit antara lain adalah komposit warna dan index (NDVI serta Moisture Index). Layer citra satelit Landsat ini menggunakan layanan ArcGIS Living Atlas.

d. Wawancara dengan warga lokal, dilakukan untuk membentuk narasi pada storytelling map serta memperoleh toponim dari beberapa unsur peta yang akan dibuat.

e. Data elevasi diperoleh dari data DEMNAS (http://tides.big.go.id/DEMNAS/) dengan resolusi 8 meter. Elevasi ini digunakan untuk menyediakan latar bentukan topografi Pulau Rote secara keseluruhan

f. Sumber data dari berbagai instansi, seperti Kemenhub, KLHK, ATR/BPN dan Pemerintah daerah Kabupaten Rote Ndao untuk menyusun layer-layer pada WebGIS Pulau Rote serta sebagai bahan analisis

Sebagian data yang disebutkan di atas digunakan untuk membantu survey lapangan (misalnya data OpenStreetMap) serta data analisis pendahuluan (misalnya data Landsat 8). Data-data tersebut juga digabungkan dengan data lain yang diperoleh untuk dijadikan sebagai layer pada WebGIS dan Storytelling map.

\subsection{Metodologi}

Penelitian ini dilaksanakan sebagaimana pada Gambar 2.2 berikut:

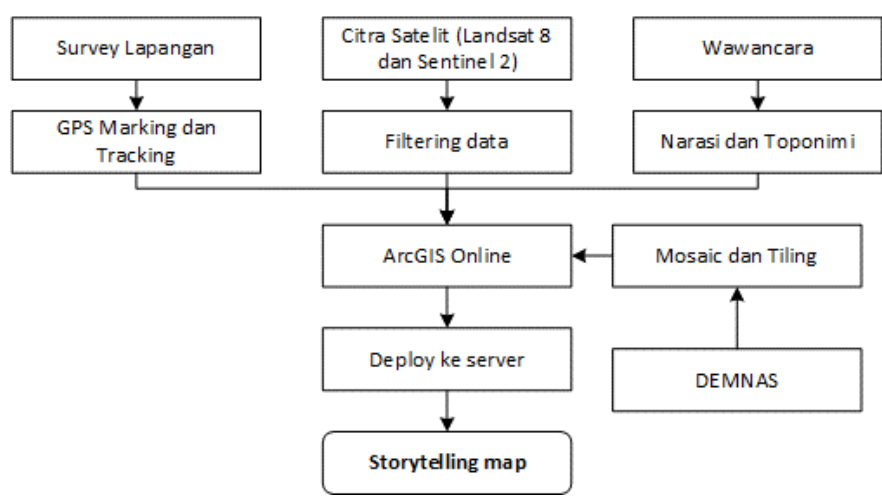

Gambar 2.2 Pelaksanaan penelitian

Tahapan yang dilakukan antara lain:

a. Persiapan

Tahap persiapan dilakukan dengan melakukan studi literatur mengenai kondisi Pulau Rote serta literatur terkait mengenai danau dan ekosistem di Pulau Rote. Pada tahap ini juga dilakukan pengumpulan data seperti citra satelit dan DEMNAS serta data-data pendukung seperti jaringan jalan dan batas administrasi di Pulau Rote. Data- data pendukung ini kemudian disimpan dalam format shapefile untuk digunakan pada perangkat lunak SWMaps pada saat survey.

\section{b. Survey Lapangan}

Survey lapangan dilakukan untuk memperoleh data spasial dan non-spasial terkait dengan pembangunan visualisasi storytelling maps di Pulau Rote. Data spasial yang diperoleh antara lain marking koordinat GPS untuk tiap posisi danau dan objek lain yang akan ditampilkan di peta berikut geotag foto pada lokasi tersebut serta hasil tracking untuk melengkapi data jaringan jalan yang sudah diperoleh sebelumnya. Data ini diperoleh dengan menggunakan perangkat lunak SWMaps dan dilakukan melalui overlay data-data pendukung yang diperoleh pada tahap persiapan

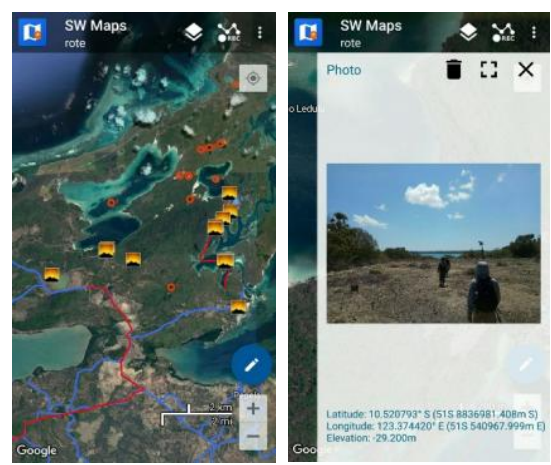

Gambar 2.3. SWMaps untuk akuisisi data di lapangan (marking dan tracking GPS serta geotagging foto)

Data non-spasial diperoleh melalui wawancara dengan penduduk lokal. Data non-spasial yang diperoleh antara lain berupa toponimi danau serta atribut yang kemudian disusun menjadi narasi untuk Storytelling Maps.

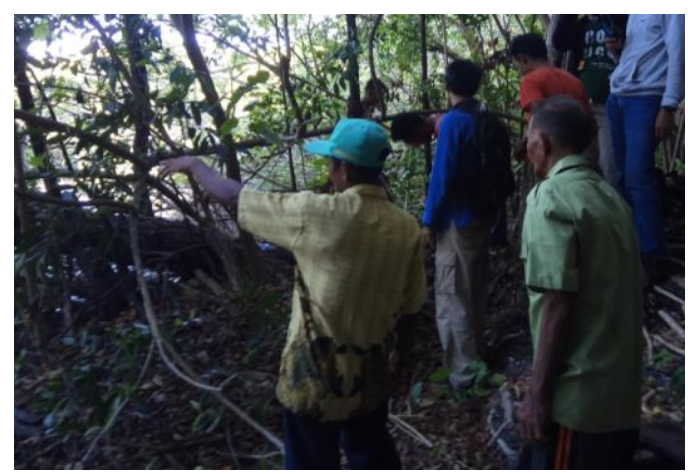

Gambar 2.4 Survey dan wawancara dengan warga di danau Lendeoen

Selain data-data tersebut, diperoleh juga data yang dihasilkan dari pengukuran lapangan, seperti pengukuran kualitas air danau yang menghasilkan nilai Dissolved Oxigen (DO), salinity, dan lain sebagainya. Data-data ini juga digunakan dalam storytelling maps Geopark4Rote yang akan disusun kemudian. 
c. Penyusunan Narasi untuk Storytelling maps

Narasi atau narrative dapat digunakan sebagai connecting tissue yang menghubungkan fakta satu dengan yang lain sehingga mudah diingat (Kosara \& MacKinlay, 2013). Pada storytelling maps Geopark4Rote, narasi disusun untuk menghubungkan berbagai data dan fakta yang diperoleh dari hasil survey lapangan dan data-data sekunder lainnya. Pada tahapan ini juga dilakukan pemilihan platform story maps yang akan digunakan sesuai dengan alur narasi yang dibuat.

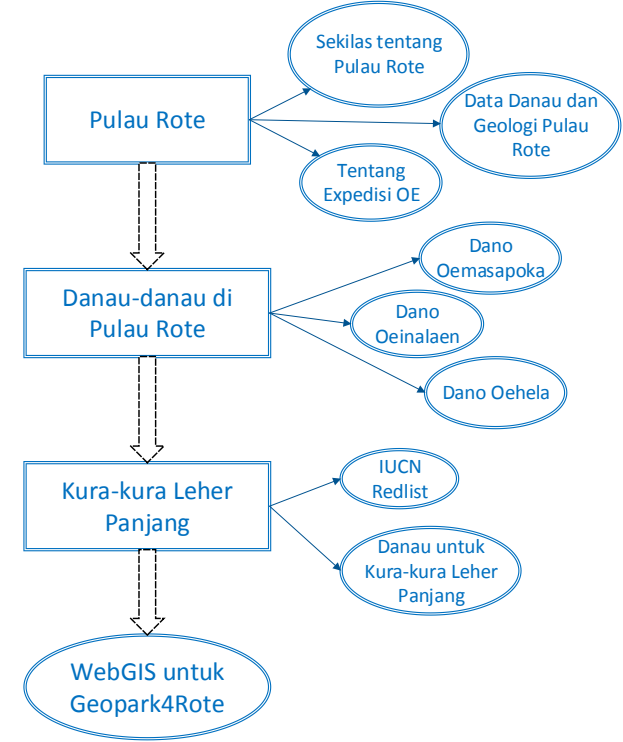

Gambar 2.5 Alur Narasi Storytelling Maps Expedition Oe

Berdasarkan hasil pengumpulan data melalui survey dan wawancara, alur narasi storytelling maps Geopark4Rote dibuat seperti pada Gambar 2.5. Narasi storytelling map Expedition Oe secara umum terbagi menjadi 4 bagian utama, yaitu penjelasan mengenai Pulau Rote secara umum, keterangan tentang danau-danau di Pulau Rote serta penjelasan mengenai kura-kura leher Panjang di Pulau Rote. Masing-masing bagian ini terdiri dari beberapa bagian data dan fakta yang bersifat lebih spesifik. Tujuan akhir dari narasi ini adalah untuk mengantarkan pengunjung website mendapatkan informasi mengenai berbagai keunikan Pulau Rote sebagai hasil dari survey Expedisi Oe, kemudian memahami latar belakang Geopark4Rote sebagai cara untuk menjaga kelestarian alam khususnya di Pulau Rote.

Pada bagian narasi awal, dijelaskan beberapa fakta mengenai Pulau Rote sebagai pengantar pengunjung website untuk mengenal lebih jauh pulau ini. Data DEMNAS dimunculkan dalam bentuk peta interaktif untuk memberikan gambaran mengenai struktur geologi dari Pulau Rote sehingga menghasilkan beberapa danau yang memiliki karakteristik berbeda. Narasi bagian kedua lebih focus kepada beberapa hasil survey khususnya di ketiga danau yang memiliki ciri unik: Dano Oemasapoka, Dano Oeinalaen dan Dano Oehela. Pembahasan terakhir adalah mengenai kura-kura leher panjang sebagai satwa endemik danau-danau di Pulau Rote yang kini terancam punah. Dengan demikian, pembaca kemudian dibawa untuk menjelajah sendiri data-data spasial yang telah dikumpulkan baik melalui Ekspedisi Oe maupun data sekunder terkait Pulau Rote pada WebGIS Pulau Rote di bagian akhir narasi.

ESRI Story Maps (ESRI, 2018) adalah perangkat lunak yang dapat digunakan untuk membuat sebuah storytelling interaktif berbasis web dengan penekanan pada data spasial. ESRI Story Maps memiliki beberapa jenis, diantaranya Cascade, Journal, Shortlist, Series, dan lain sebagainya. Untuk penyusunan Storytelling maps Expedisi Oe ini digunakan jenis Cascade yang dapat menggambarkan narasi yang disusun sesuai dengan Gambar 5 .

\section{d. Pembangunan Visualisasi Storytelling maps}

Pembangunan storytelling maps sendiri dilakukan sebagaimana pada Gambar 2. Data yang diperoleh dari berbagai sumber serta hasil survey lapangan kemudian diolah dan dikompilasi pada sebuah WebGIS Pulau Rote. Beberapa tahapan yang dilakukan antara lain:

i. Pembangunan WebGIS pada platform ArcGIS Online. WebGIS Pulau Rote dibuat dengan menggunakan ArcGIS Online berdasarkan data-data spasial yang telah diperoleh sebelumnya, seperti data batas administrasi dan jaringan jalan di Pulau Rote.

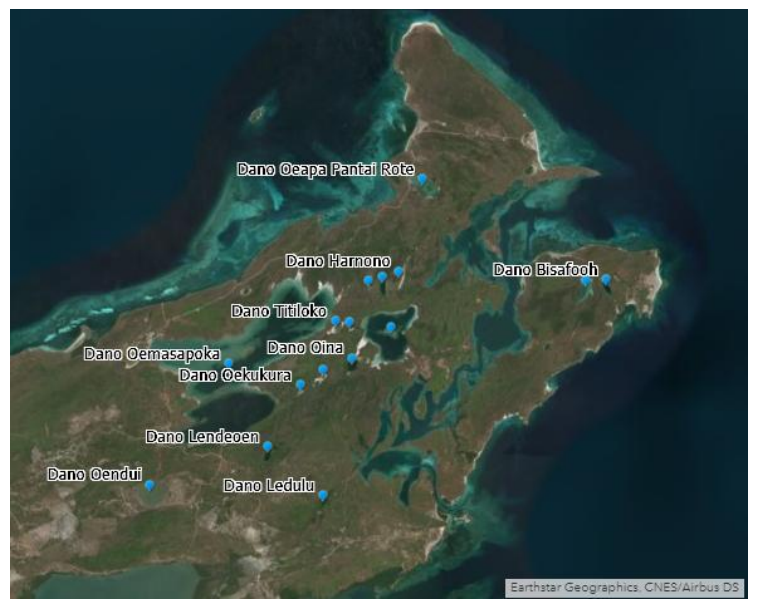

Gambar 2.6 Sebagian label danau hasil survey

ii. Penyusunan layer nama danau Pulau Rote dengan toponim yang didapatkan dari hasil survey (Gambar 2.6). Toponim disusun berdasarkan atas hasil wawancara dengan warga serta hasil marking titik danau di lapangan. Hasil pelabelan nama danau dari wawancara ini juga dilakukan untuk verifikasi dan koreksi data nama danau yang diperoleh dari sumber, yaitu dari Google Maps dan OpenStreetMap (OSM).

iii. Pembuatan mosaic DEMNAS dan pembentukan tiling untuk WebGIS.

DEMNAS untuk Pulau Rote diunduh melalui situs yang telah disediakan oleh BIG. Data DEMNAS ini diperoleh 
dalam bentuk sheet, dimana keseluruhan Pulau Rote terdiri dari 8 sheet yang berbeda. Agar dapat ditampilkan pada WebGIS, proses mosaic dan tiling perlu dilakukan terlebih dahulu sebelum layer tersebut diunggah pada WebGIS Pulau Rote. Proses mosaicking dan tiling dilakukan dengan menggunakan perangkat lunak ArcGIS Pro.

iv. Penambahan dan filtering layer Landsat Multispectral. Layer Landsat multispectral disediakan oleh ArcGIS Living Atlas. Pada WebGIS Pulau Rote yang dibuat, layer Living Atlas perlu dilakukan pengaturan terlebih dahulu agar dapat digunakan sebagai layer multitemporal (time-enabled layer). Pengaturan dilakukan dengan mengaktifkan slider time-enabled layer atau memilih citra Landsat sesuai kriteria dengan menggunakan filtering (Gambar 2.7).

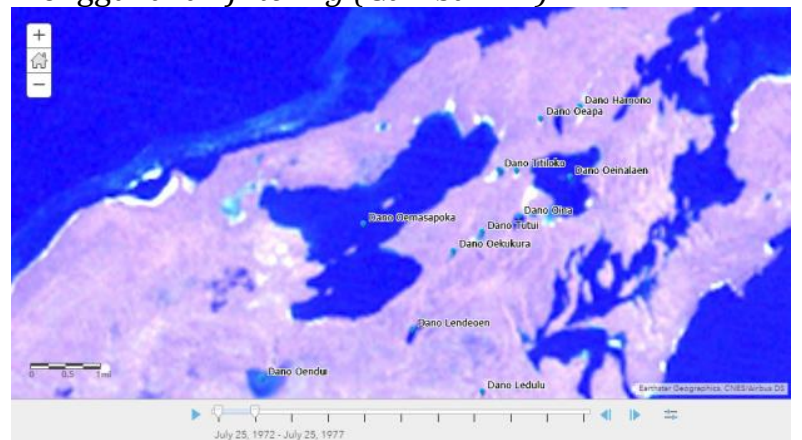

Gambar 2.4 Layer Landsat Multispectral menampilkan NDVI dengan time-enabled slider (mosaik citra tahun 1972-1977)

v. Penyusunan Storytelling maps. ESRI Storytelling maps yang dipilih menggunakan format Storytelling Cascade. Narasi untuk storytelling map disusun berdasarkan hasil wawancara dengan penduduk lokal dan dilengkapi dengan hasil penelitian yang diperoleh selama survey. Storytelling maps dibangun di atas WebGIS Pulau Rote yang telah disusun sebelumnya. Hasil akhir storytelling maps ini kemudian diunggah (deploy) pada server berbasis Github.

\section{Hasil dan Pembahasan}

Data yang diperoleh dari hasil survey lapangan pada danau-danau di Pulau Rote kemudian dikompilasi. Hasil penyusunan storytelling maps dan webgis masing-masing dipublikasikan melalui alamat domain http://geopark4rote.com dan subdomain http://geopark4rote.com/webgis.

Masing-masing keluaran dalam bentuk storytelling maps dan WebGIS dibahas sebagai berikut:

\subsection{Storytelling maps}

Storytelling maps merupakan salah satu metode visualisasi berbasis cerita atau narasi. Dengan menampilkan data-data hasil penelitian dalam bentuk narasi, maka pengguna website dapat lebih mudah memahami pesan yang akan disampaikan.

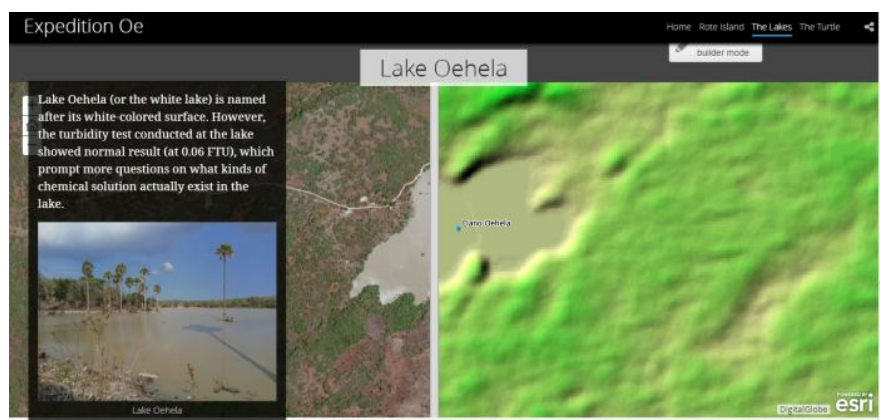

Gambar 3.1 Storytelling map Expedisi Oe

Storytelling maps yang telah disusun (Gambar 3.1) mengkombinasikan antara data spasial dan data nonspasial yang telah diperoleh melalui survey. Narasi pada storytelling map disusun berdasarkan atas hasil studi literatur dan wawancara dengan penduduk lokal.

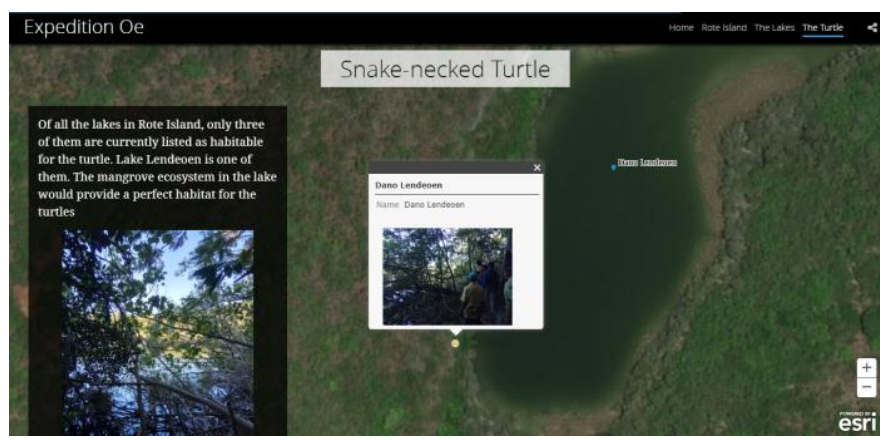

Gambar 3.2 Informasi mengenai kura-kura leher ular di Storytelling map Rote

Selain menonjolkan keunikan beberapa danau di Pulau Rote, Storytelling map tersebut juga memberikan informasi mengenai kura-kura leher ular (Chelodina mccordi) yang merupakan binatang endemik di pulau ini (Gambar 3.2). Pada narasi storytelling map diberikan lokasi danau yang sesuai dengan habitat hewan tersebut agar menimbulkan kesadaran untuk menjaga ekosistem di Pulau Rote, khususnya pada danau-danau yang menjadi habitat mereka.

\subsection{Pembangunan WebGIS Pulau Rote}

WebGIS Pulau Rote disusun pada platform ArcGIS online dan berisi berbagai layer yang telah dibuat sebelumnya (Gambar 3.3). WebGIS ini berfungsi sebagai landasan pada saat pembangunan storytelling map. WebGIS yang dibuat memiliki antarmuka sederhana dan beberapa fungsi analisis dan visualisasi.

Fungsi visualisasi pada WebGIS Pulau Rote merupakan pengaturan simbologi layer dan penggantian basemap serta fungsi navigasi pada umumnya. Adapun beberapa fungsi analisis yang dapat digunakan pada WebGIS Pulau 
Rote antara lain adalah pengukuran, filter layer, penggambaran pada layer, time slider dan swipe. Disamping itu, fungsi add data dapat digunakan untuk menambahkan data dari berbagai sumber yang terhubung dengan infrastruktur data spasial Indonesia. Sebagai contoh, data RTRW Provinsi Nusa Tenggara Timur dapat ditambahkan dari jaringan http://gistaru.atrbpn.go.id/ sebagai wali data tata ruang di daerah tersebut.

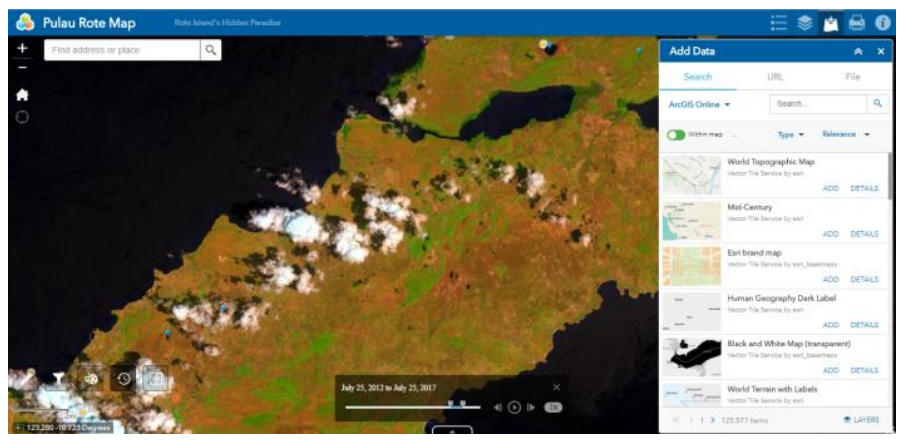

Gambar 3.3 WebGIS Pulau Rote dengan fungsi TimeSlider Aktif.

Disamping fungsi analisis, WebGIS Pulau Rote ini juga dapat digunakan sebagai sumber data spasial untuk digunakan oleh berbagai instansi dan stakeholder terkait. Ketersediaan layer dengan informasi yang terverifikasi, misalnya toponimi danau, dapat digunakan sebagai acuan dalam pengambilan keputusan. Koreksi dilakukan pada beberapa nama danau yang kurang tepat sesuai dengan keterangan dari warga lokal. Perbandingan nama danau sebelum dan sesudah wawancara dengan warga ditunjukkan pada Tabel 3.1.

Tabel 3.1 Koreksi Toponimi Danau di Pulau Rote

\begin{tabular}{|c|c|}
\hline Toponimi Google & Toponimi Hasil Wawancara \\
\hline Dano Bisanduli & Dano Oeapa Pantai Rote \\
\hline (belum ada nama) & Dano Oeapa \\
\hline Dano Olifoe & Dano Sinioen \\
\hline Dano Oinadale & Dano Harmono \\
\hline Dano Fitiloko & Dano Titiloko \\
\hline (belum ada nama) & Dano Oelakas \\
\hline Dano Ledulu & Dano Oeinalaen \\
\hline Dano Sapuoen & Dano Oina \\
\hline Dano Lindu & Dano Lendeoen \\
\hline (belum ada nama) & Dano Ledulu \\
\hline
\end{tabular}

WebGIS Pulau Rote juga berfungsi sebagai pusat informasi untuk penelitian dan pariwisata. Dengan menggunakan analisis WebGIS seperti swipe (Gambar 3.4), pengguna web dapat melakukan perbandingan antara data topografi dari DEMNAS dengan citra satelit sehingga berbagai informasi dapat diperoleh, misalnya untuk membandingkan antara kenampakan geologi dengan kenampakan citra satelit.

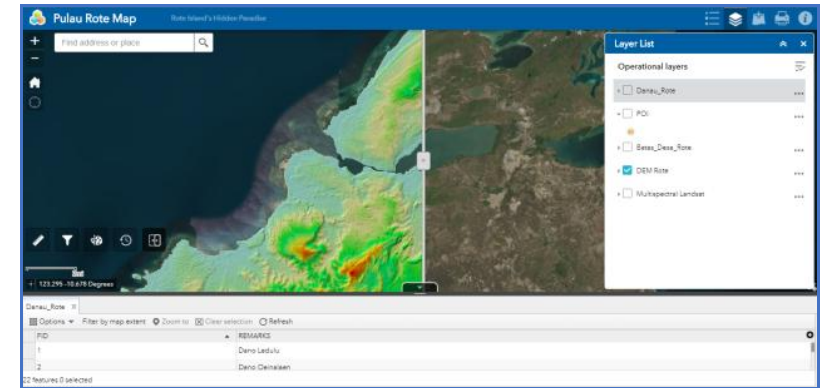

Gambar 3.4 Fungsi Swipe pada WebGIS Pulau Rote

\section{Kesimpulan}

Pulau Rote menyimpan banyak keunikan yang memiliki potensi wisata yang sangat besar. Meskipun demikian, besarnya potensi wisata tersebut belum sepenuhnya dimanfaatkan dengan baik. Penelitian ini merupakan tahap awal dalam menggali berbagai fakta yang dapat menarik minat wisatawan. Penyajian informasi Pulau Rote dalam bentuk peta memudahkan analisis spasial dilakukan dengan menggabungkan informasi dari berbagai instansi yang berbeda. Dengan pembangunan WebGIS akan memungkinkan data-data yang diperoleh dari berbagai instansi dapat dianalisis pada satu platform, sekaligus sebagai dokumentasi penelitian yang telah dilakukan maupun penelitian yang akan datang.

Publikasi dalam bentuk storytelling map bersumber dari hasil penelitian yang diperoleh dari keterangan warga lokal. Dalam bentuk narasi, storytelling map tersebut juga berisi peta interaktif yang dapat digunakan untuk mendapatkan informasi lebih jauh mengenai persebaran spasial berbagai objek wisata, khususnya danau-danau di Pulau Rote. Selain itu, diseminasi informasi dalam bentuk storytelling maps ini juga mengandung informasi mengenai kura-kura leher panjang yang merupakan satwa endemik di Pulau Rote. Dengan demikian, pembangunan storytelling maps diharapkan memiliki dua keuntungan, yaitu sebagai media diseminasi hasil penelitian sekaligus sarana untuk menarik minat wisatawan.

Penelitian ini merupakan hasil awal survey Pulau Rote yang bertujuan untuk membangun website sebagai media diseminasi dan publikasi mengenai potensi Pulau Rote. Publikasi penelitian melalui Geopark4Rote juga bertujuan untuk menarik minat para peneliti dalam menggali potensi Pulau Rote sebagai kandidat Geopark di Indonesia.

\section{Pernyataan Konflik Kepentingan}

Penulis menyatakan tidak ada konflik kepentingan dalam artikel ini (The authors declare no competing interest).

\section{Referensi}

Cortes, N. L. (2018). Conceptual Framework for Interactive Cartographic Storytelling. Thesis, University of Twente. 
Endarwin, W., Ul-Hasanah, A., Vazquez, R. I., \& Kusrini, M. D. (2005). Studi Pendahuluan: Keberadaan KuraKura Rote (Chelodina Mccordi, Rhodin 1994) Di Pulau Rote, Nusa Tenggara Timur. Media Konservasi, 10(2). https://doi.org/10.29243/MEDKON.10.2.\%P

ESRI. (2018). Esri Story Maps. Retrieved January 21, 2019, from https://storymaps.arcgis.com/en/

Feeney, A. E. (2017). Beer-trail maps and the growth of experiential tourism. Cartographic Perspectives, O(87), 9-28. https://doi.org/10.14714/CP87.1383

Graves, M. (2015). Spatial Narratives of Struggle and Activism in the Del Amo and Montrose Superfund Cleanups: A Community-Engaged Web GIS Story Map. Retrieved from https://spatial.usc.edu/wpcontent/uploads/2015/09/GravesMallory.pdf

Julzarika, A., Puguh Laksono, D., Subehi, L., Kurniai Dewi, E., Kayat, K., A Sofiyuddin, H., \& Fitri Isma Nugraha, M. (2018). Comprehensive integration system of saltwater environment on Rote Island using a multidisciplinary approach. Journal of Degraded and Mining Lands Management, 06(01), 1553-1567. https://doi.org/10.15243/jdmlm.2018.061.1553

Kabupaten Rote Ndao. (2018). Website Resmi Kabupaten Rote Ndao. Retrieved June 9, 2018, from http://www.rotendaokab.go.id/geografis/

Kerski, J. J. (2015). Geo-awareness, geo-enablement, geotechnologies, citizen science, and storytelling: Geography on the world stage. Geography Compass, 9(1), 14-26. https://doi.org/10.1111/gec3.12193

Kosara, R., \& MacKinlay, J. (2013). Storytelling: The next step for visualization. Computer, 46(5), 44-50. https://doi.org/10.1109/MC.2013.36

Nikodemus, P. N., Susanto, S., \& Sudira, P. (2004). Prediksi Sumberdaya Air di Pulau Kecil: Studi Kasus di Pulau Rote Nusa Tenggara Timur. Jurnal Manusia dan Lingkungan (Vol. XI). Pusat Penelitian Lingkungan Hidup Universitas Gadjah Mada. Retrieved from https://www.neliti.com/id/publications/113391/pr ediksi-sumberdaya-air-di-pulau-kecil-studi-kasus-dipulau-rote-nusa-tenggara-t

Thöny, M., Schnürer, R., Sieber, R., Hurni, L., \& Pajarola, R. (2018). Storytelling in interactive 3D geographic visualization systems. ISPRS International Journal of Geo-Information, $7(3)$. https://doi.org/10.3390/ijgi7030123

Zitierung, E., Wright, C. ;, \& Lewis, B. (2012). On the edge of crisis: contending perspectives on development, tourism, and community participation on Rote Island. Indonesia. ASEAS-Österreichische Zeitschrift Für Südostasienwissenschaften, 5(1), 102-127. https://doi.org/10.4232/10.ASEAS-5.1-6 